\section{Rose (Rosa dilecta) Response to Simulated Herbicide Drift}

\author{
Kassim Al-Khatib ${ }^{1}$ \\ Robert Parker', and \\ E. Patrick Fuerst ${ }^{2}$
}

Additional index words. bromoxynil, chlorsulfuron, crop injury, glyphosate, herbicide drift, herbicide symptoms, thifensulfuron, 2,4-D

Summary. This study evaluated the response of rose to different herbicides applied as simulated drift. Chlorsulfuron $\{2$-chloro-N-[[(4methoxy-6-methyl-1,3,5-triazin-2yl)amino]carbonyl]benzenesulfonamide , thifensulfuron \{ 3[ [ [ [ (4-methoxy-6methyl-1,3,5-triazin-2-

yl)amino]carbonyl]amino]sulfonyl]-2thiophenecarboxylic acid\},

bromoxynil(3,5-dibromo-4-

hydroxybenzonitrile $), \quad 2,4-\mathrm{D}[(2,4-$ dichlorophenoxy)acetic acid], glyphosate [N-(phosphonomethyl) glycine], and a combination of 2,4-D and glyphosate were applied over the top of established rose plants at $1 / 3$, $1 / 10,1 / 33$, and $1 / 100$ of the maximum labeled rate for grains. All herbicides injured rose. The greatest injury was from chlorsulfuron and 2,4$\mathrm{D}$, and the least injury was from bromoxynil and glyphosate. Plants recovered from the injury caused by all treatments except for the highest rates of chlorsulfuron and 2,4-D, which continued to show significant injury at the end of the growing season. Although all herbicides had characteristic symptoms, some of these were very similar to those caused by other stresses. Therefore, because of the potential ambiguity of visual symptoms, any allegation about herbicide drift should be based on a report of all symptoms and should be supported by residue analysis.

'Irrigated Agriculture Research and Extension Center, Washington State University, Prosser, WA 99350.

${ }^{2}$ Department of Crop and Soil Science, Washington State University, Pullman, WA 99163.

Contribution 9201-14 from the Washington State College of Agriculture Research Center.
$\mathrm{R}$ ecent urbanization of many agricultural areas in south-central Washington has placed residential tracts in fairly close proximity to agricultural fields. Application of herbicides on these fields may result in unintentional drift to nearby residential areas. This unwanted feature of herbicide usage, referred to as offtarget herbicide drift, causes loss of weed control and raises concerns of potential exposure to humans, animals, and plants.

Rose is a popular landscaping plant in south-central Washington. Growth and productivity of rose, however, may be hindered by diseases, insects, nutrient imbalance, ah-pollutants, adverse environmental conditions, herbicides, and other injuries (Horst, 1983). Often these stresses result in damage and abnormal rose growth.

There have been many allegations in south-central Washington that herbicides are drifting onto home landscapes from nearbywheat fields, causing damage to rose and other home garden plants. These allegations are based on visual symptoms that are sometimes similar to those caused by factors other than herbicides. Therefore, any judgment of the cause of damage requires as much information as possible, not only about the identity of symptoms for each herbicide, but also about the pattern of symptom development over time.

Chlorsulfuron, thifensulfuron, bromoxynil, 2,4-D, and glyphosate are used extensively to control weeds in wheat fields and/or fallow. The application of these herbicides is normally in early spring when rose plants are metabolically active and highly sensitive to herbicides.

Herbicides such as 2,4-D, dicamba (3,6-dichloro-2-methoxy-benzoic acid $)$, triclopyr [((3,5,6-trichloro2-pyridinyl)oxy)acetic acid], picloram (4-amino-3,5,6-trichloro-2-pyridinecarboxylic acid), tebuthiuron $\{\mathrm{N}-[5-$ (1,1-dimethylethyl)-1,3,4-thiadiazol2-yl]-N-N-dimethylurea], metsulfuron, chlorsulfuron, and glyphosate are used extensively to control weedy rose species, including multiflora rose (Rosa multiflora Thunb.), Macartney rose (Rosa bracteata J.C. Wendl.), and prickly rose (Rosa acicularis Lindl.) (Bowes, 1981; Derr, 1989; Mayer and Bovey, 1984, 1990). However, the response of cultivated rose to herbicides at simulated drift rates has not been reported.

The objectives of this research were to determine the susceptibility of rose to selected herbicides applied at simulated drift rates and to collect information about herbicide injury symptoms that would be diagnostic

Table 1. Visual injury to rose plants 14 days after simulated drift with six herbicides applied in Spring 1990 and 1991.

\begin{tabular}{|c|c|c|c|c|}
\hline \multirow[b]{2}{*}{ Herbicide } & \multicolumn{4}{|c|}{ Rate (fraction of maximum use rate) } \\
\hline & $1 / 100$ & $1 / 33$ & $1 / 10$ & $1 / 3$ \\
\hline \multicolumn{5}{|c|}{1990 injury $(\%)$} \\
\hline Chlorsulfuron & 37 & 48 & 58 & 63 \\
\hline Thifensulfuron & 20 & 33 & 47 & 53 \\
\hline Bromoxynil & 0 & 8 & 33 & 40 \\
\hline $2,4-\mathrm{D}$ & 8 & 23 & 47 & 53 \\
\hline Glyphosate & 3 & 7 & 8 & 37 \\
\hline 2,4-D + Glyphosate & 3 & 10 & 37 & 60 \\
\hline
\end{tabular}

LSD (0.05) for rates within the same herbicide 10

LSD (0.05) for herbicides within the same rate 11

\begin{tabular}{|c|c|c|c|c|}
\hline & & iury & & \\
\hline Chlorsulfuron & 20 & 28 & 33 & 41 \\
\hline Thifensulfuron & 9 & 17 & 23 & 30 \\
\hline Bromoxynil & 2 & 8 & 17 & 22 \\
\hline $2,4-\mathrm{D}$ & 8 & 10 & 22 & 25 \\
\hline Glyphosate & 0 & 5 & 5 & 20 \\
\hline 2,4-D + Glyphosate & 0 & 5 & 17 & 17 \\
\hline
\end{tabular}

LSD (0.05) for rates within the same herbicide 5 LSD (0.05) for herbicides within the same rate 6 
and helpful in evaluating allegations of herbicide drift on rose.

Experiments were conducted at the Irrigated Agriculture Research and Extension Center, Prosser, Wash. The soil was Warden fine sandy loam soil (coarse-silty, mixed, mesic Xerollic Camborthids) with organic matter content of $0.8 \%$ and $\mathrm{pH} 8.1$.

One-year-old "Assorted" rose plants were planted on 20 Apr. 1989, using standard grower practices. Roses were spacedwith $0.9 \mathrm{~m}$ within and 3.6 $\mathrm{m}$ between rows. Roses were monitored for insects and diseases and were treated accordingly. The experimental area was kept weed-free by mechanical cultivation and hand-hoeing. Plants were irrigated weekly by furrow irrigation. Roses were treated with herbicides 1 or 2 years (1990 and 1991, respectively) after planting.

Herbicide treatments were made early on 30 Apr. 1990 and 13 May 1991, when new growth was $15-\mathrm{cm}$ long. Herbicides were applied over the top of the rose plants with a $\mathrm{CO}_{2}$ pressurized knapsack sprayer equipped with two 8006 flat-fan nozzles and calibrated to deliver 374 literžha $^{-1}$ at 103 $\mathrm{kPa}$. To eliminate drift to surrounding plants, the plots were sprayed in the early morning when the air was calm $\left(<3 \mathrm{kmžh}^{-1}\right)$, and a plastic shield was placed between plots during application. Herbicides were applied at $1 /$ $100,1 / 33,1 / 10$, and $1 / 3$ of the maximum labeled rate for fallow or small grains. Rates used were $0.26,0.88$, 2.63 , and 8.75 gžha $^{-1}$ for thifensulfuron and chlorsulfuron; 4.26, 14.20, 42.6, and 142 gžha $^{-1}$ for bromoxynil and glyphosate; 11.22, 37.4, 112.2, and 374 gžha $^{-1}$ for 2,4-D; and $3+3,10+11$, $29+32$, and $96+105$ gžha $^{-1}$ for $2,4-\mathrm{D}$ + glyphosate. The 2,4-D + glyphosate combination is widely used in southcentral Washington to control weeds in fallow. All spray mixtures included nonionic surfactant [X-77 spreader (alkylarylpoly-oxethylene, glycols, free fatty acids, and isopropanol)] at $0.25 \%$ (v/v). Control plots were sprayed with a mixture of water and nonionic surfactant at $0.25 \%(\mathrm{v} / \mathrm{v})$.

The symptoms developed were observed every 3 days during the entire growing seasons of 1990 and 1991. Visual estimates of injury were determined every 2 weeks. The injury rating was based on $0=$ no injury and $100=$ complete kill.

The experimental design was a split plot with three replications. The main plots were the six herbicides, and the five subplots were the rates of each herbicide. Individual subplots contained two plants with another two plants serving as a buffer between adjoining subplots. One row of nontreated plants separated each row of

plots. Data were tested for homogeneity of variance and normality of distribution (Neter et al., 1985), and data were log-transformed as needed before the analysis of variance. When transformation was necessary, the data were transformed back to their original scales for presentation in tables. Because her-

Table 2. Visual injury to rose plants 30 days after simulated drift with six herbicides applied in Spring 1990 and 1991.

\begin{tabular}{lrccc}
\hline & \multicolumn{4}{c}{ Rate (fraction of maximum use rate) } \\
\cline { 2 - 5 } Herbicide & \multicolumn{1}{c}{$\mathbf{1 / 3 3}$} & $\mathbf{1 / 1 0}$ & $\mathbf{1 / 3}$ \\
\hline \hline & \multicolumn{4}{c}{ 1990 injury (\%) } \\
Chlorsulfuron & 33 & 43 & 56 & \\
Thifensulfuron & 8 & 20 & 45 & 65 \\
Bromoxynil & 0 & 5 & 12 & 55 \\
2,4-D & 10 & 25 & 42 & 52 \\
Glyphosate & 2 & 5 & 8 & 32 \\
2,4-D + Glyphosate & 2 & 10 & 22 & 50
\end{tabular}

$\operatorname{LSD}(0.05)$ for rates within the same herbicide 9

LSD $(0.05)$ for herbicides within the same rate 9

\begin{tabular}{lrrrr} 
& \multicolumn{3}{c}{ 1991 injury (\%) } \\
Chlorsulfuron & 18 & 50 & $\mathbf{5 5}$ & 62 \\
Thifensulfuron & 10 & 18 & 28 & 32 \\
Bromoxynil & 0 & 5 & 13 & 23 \\
2,4-D & 7 & 15 & 22 & 35 \\
Glyphosate & 4 & 12 & 17 & 33 \\
2,4-D + Glyphosate & 3 & 12 & 17 & 28
\end{tabular}

LSD (0.05) for rates within the same herbicide 7 LSD (0.05) for herbicides within the same rate

9

Table 3. Visual injury to rose plants 60 days after simulated drift with six herbicides applied in Spring 1990 and 1991.

\begin{tabular}{lcccr}
\hline & \multicolumn{4}{c}{ Rate (fraction of maximum use rate) } \\
\cline { 2 - 5 } Herbicide & $\mathbf{1 / 1 0 0}$ & $\mathbf{1 / 3 3}$ & $\mathbf{1 / 1 0}$ & $\mathbf{1} 3$ \\
\hline \hline & & 1990 injury (\%) & \\
Chlorsulfuron & 2 & 7 & $\mathbf{2 0}$ & 48 \\
Thifensulfuron & 0 & 0 & 2 & 0 \\
Bromoxynil & 0 & 3 & 0 & 17 \\
2,4-D & 0 & 0 & 0 & 10 \\
Glyphosate & 0 & 0 & 7 & 10
\end{tabular}

LSD (0.05) for rates within the same herbicide 6 LSD (0.05) for herbicides within the same rate 7

\begin{tabular}{lrrrr} 
& \multicolumn{3}{c}{1991 injury $(\%)$} & 68 \\
Chlorsulfuron & 20 & 43 & 55 & 23 \\
Thifensulfuron & 3 & 7 & 20 & 10 \\
Bromoxynil & 0 & 0 & 8 & 37 \\
$2,4-D$ & 5 & 17 & 32 & 13 \\
Glyphosate & 0 & 8 & 10 & 25 \\
2,4-D + Glyphosate & 0 & 3 & 18 &
\end{tabular}

LSD (0.05) for rates within the same herbicide 7 LSD (0.05) for herbicides within the same rate 8 
bicide $\times$ year interactions occurred, the means are presented separately for each year. Mean separation was by LSD at the 0.05 level.

In general, symptoms of all herbicides developed faster in 1990 compared to 1991 . At $1 / 3$ of the use rate, all herbicides caused significant injury 14 days after treatment (DAT).
Chlorsulfuron, thifensulfuron, and 2,4$\mathrm{D}$ cause the greatest injury (Table 1 ). Only chlorsulfuron and thifensulfuron caused significant injury at the lowest rate $(1 / 100$ of the use rate).

Symptoms of all herbicides except bromoxynil were more apparent 30 DAT than at 14 DAT in 1991, whereas in 1990, herbicide injury was

Table 4. Visual injury to rose plants 90 days after simulated drift with six herbicides applied in Spring 1990 and 1991.

\begin{tabular}{|c|c|c|c|c|}
\hline \multirow[b]{2}{*}{ Herbicide } & \multicolumn{4}{|c|}{ Rate (fraction of maximum use rate) } \\
\hline & $1 / 100$ & $1 / 33$ & $1 / 10$ & $1 / 3$ \\
\hline \multicolumn{5}{|c|}{1990 injury (\%) } \\
\hline Chlorsulfuron & 0 & 0 & 0 & 33 \\
\hline Thifensulfuron & 0 & 0 & 3 & 3 \\
\hline Bromoxynil & 0 & 0 & 0 & 0 \\
\hline $2,4-\mathrm{D}$ & 0 & 2 & 7 & 15 \\
\hline Glyphosate & 0 & 0 & 2 & 3 \\
\hline 2,4-D + Glyphosate & 0 & 0 & 0 & 5 \\
\hline
\end{tabular}

LSD (0.05) for rates within the same herbicide 6

LSD (0.05) for herbicides within the same rate 7

$\begin{array}{llllr}\text { Chlorsulfuron } & 0 & 7 & 8 & 32 \\ \text { Thifensulfuron } & 0 & 0 & 0 & 0 \\ \text { Bromoxynil } & 0 & 0 & 0 & 0 \\ \text { 2,4-D } & 0 & 0 & 0 & 15 \\ \text { Glyphosate } & 0 & 0 & 0 & 0 \\ \text { 2,4-D + Glyphosate } & 0 & 0 & 0 & 0\end{array}$

1991 injury (\%)

LSD (0.05) for rates within the same herbicide 5

LSD (0.05) for herbicides within the same rate 6



Fig. 1. Flower malformation caused by chlorsulfuron treatment.

less or similar at 30 DAT compared to 14 DAT. Chlorsulfuron showed the greatest injury 30 DAT, whereas bromoxynil showed the least injury (Table 2). Plants treated with bromoxynil had partially recovered from injury.

At 60 DAT in 1990, plants showed no injury symptoms from all rates of bromoxynil and thifensulfuron, the lowest three rates of glyphosate and 2,4-D plus glyphosate, the lowest two rates of 2,4-D, and the lowest rate of chlorsulfuron. In 1991, however, the recovery was slower than in 1990, and only the lowest two rates of thifensulfuron, bromoxynil, and 2,4-D plus glyphosate, and the lowest rate of glyphosate completely recovered from previous injury (Table 3). All treatments in 1991 except chlorsulfuron and 2,4-D had similar or less injury at 60 DAT than at 30 DAT (Table 3 vs. Table 2).

In the middle of the growing season (90 DAT) in both years, only chlorsulfuron and 2,4-D were still showing injury (Table 4). At the end of the 1990 growing season (120 DAT), only the highest rate of chlorsulfuron resulted in significant injury, whereas in 1991, the highest rate of both chlorsulfuron and 2,4-D continued to give significant injury (data not shown). The prolonged injury caused by chlorsulfuron and 2,4$\mathrm{D}$ to rose plants may be due in part to the high mobility of these herbicides in plants (Al-Khatib et al., 1992) as well as extreme sensitivity of rose to these herbicides (Table 1).

Injury symptoms varied among herbicides. Chlorsulfuron symptoms ranged from general chlorosis at the highest two rates to mottled chlorosis at the lower rates. Leaves were wilted, crinkled, and stiffer than normal. At higher chlorsulfuron rates, leaves on the upper parts of plants turned purple. The purple color was more intense on the abaxial side of the leaves. Leaves developing after treatment were chlorotic, narrow, stunted, and distorted with necrotic leaf margins. The intensity of these symptoms and the number of leaves affected increased as the rate of herbicide increased. Chlorsulfuron treatment caused death of shoot tips, but only the highest rate caused stem dieback. All chlorsulfuron rates caused flower malformation (Fig. 1). Growth ceased after treatments and subsequent regrowth was slow. Growth 


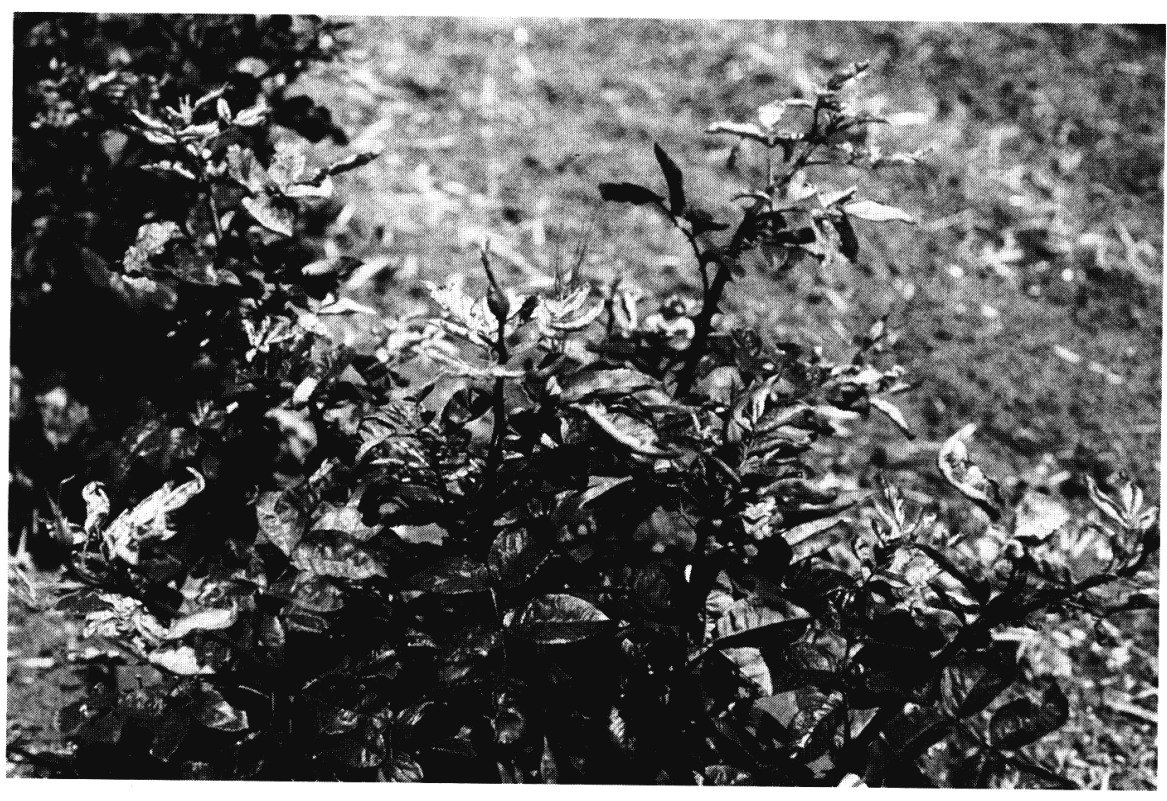

Fig. 2. Leaf chlorosis caused by thifensulfuron treatment.

after treatment also was characterized by increased branching, shortened nodes, and stunting. Growth, flower buds, and blooms appeared normal at 90 DAT, except at the highest rate chlorsulfuron.

Symptoms of thifensulfuron were similar to chlorsulfuron, only less severe (Fig. 2). Death of the shoot tip occurred at the highest rate. Leaves did not turn purple as they did with chlorsulfuron. Recovery to normal growth was faster with thifensulfuron than with chlorsulfuron. Growth ceased for a short period of time after treatment (14 DAT) with thifensulfuron, and subsequent growth was slow with increased lateral growth. At 90 DAT, growth, flower buds, and blooming were normal at all rates of thifensulfuron.

Rose developed leaf crinkling and necrotic spots, usually surrounded by a chlorotic zone, within 3 days after bromoxynil treatment (Fig. 3). New growth was normal and not inhibited. Plants recovered quickly from bromoxynil treatment, particularly at the lower rates.

Treatment with $2,4-\mathrm{D}$ at the $1 /$

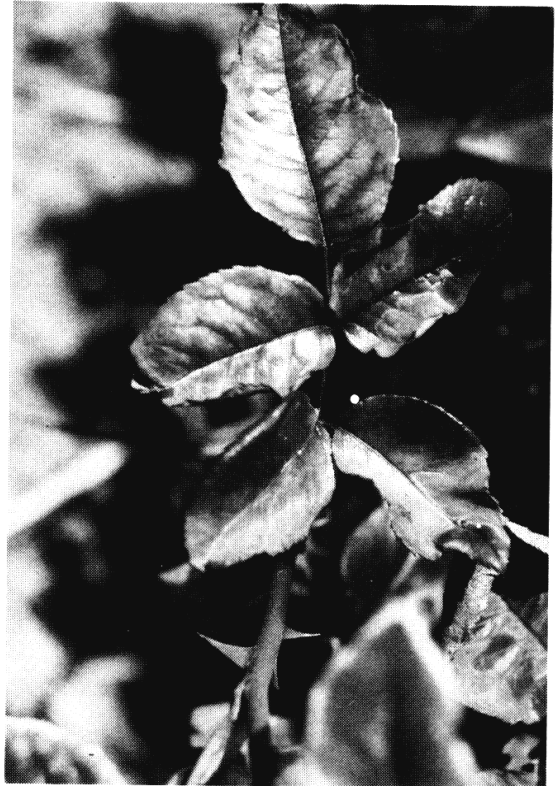

Fig. 3. Necrotic spots surrounded by chlorotic zone caused by bromoxynil treatment.

33 rate and higher caused epinasty of the stems and petioles, leaf crinkling, curling, and cupping within 2 DAT. Developing leaves were narrow, curled, and cupped, and veins were discolored (Fig. 4). General chlorosis and death of shoot tips developed by 7 DAT at the two highest rates. Growth was normal at 90 DAT at the lowest three rates, but symptoms continued until the end of the growing season at the highest rate.

At 7 DAT, glyphosate caused the development of narrow leaves, distorted leaf shape, chlorosis of young

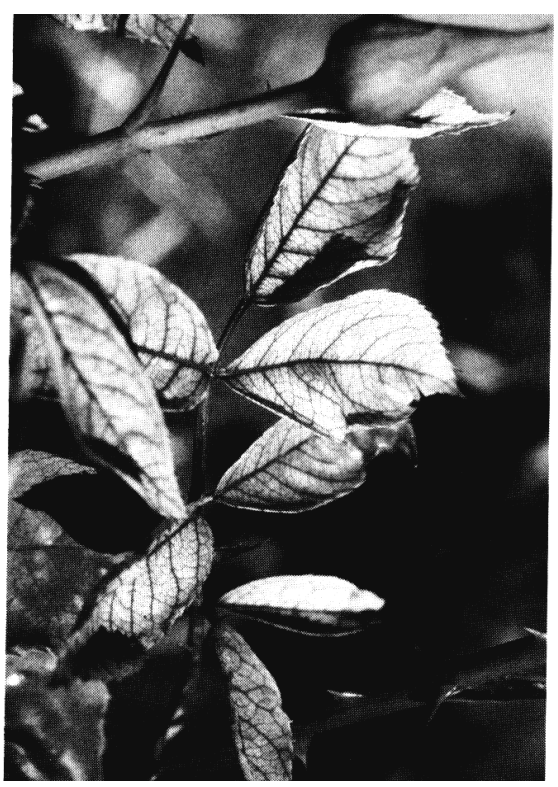

Fig. 5. Leaf chlorosis caused by glyphosate treatment.

Fig. 4. Narrow leaves caused by 2,4-D applied to roses. 


\section{TECHNOLOGY AND PRODUCT REPORTS}

leaves (veins retained green color), cupping of developing leaves, and crinkling (Fig. 5). As the rate increased, the intensity of the symptoms and the number of leaves with symptoms increased, and the stem elongation was reduced. At 60 DAT, only the highest rate produced abnormally smaller flower size than the untreated plants. At 90 DAT, growth was normal at all rates of glyphosate.

Symptoms from the combination of 2,4-D and glyphosate were similar to those described earlier for the 2,4D treatment. Slight symptoms of glyphosate injury developed 14 DAT, but these disappeared within 10 days. All rates resulted in normal growth at the end of the growing season, except the highest rate that gave slight 2,4-D symptoms.

This study clearly illustrates that rose plants are sensitive to chlorsulfuron, 2,4-D, thifensulfuron, glyphosate, and bromoxynil, and these herbicides might cause significant damage if they drift in sufficient quantities on rose plants. Although each herbicide caused characteristic symptoms, some of these symptoms may resemble those caused by diseases, mineral deficiencies, and environmental stresses (Horst, 1983). Therefore, because of the potential ambiguity of visual symptoms, reports should be based on all symptoms and herbicide residue analysis.

\section{Literature Cited}

Al-Khatib, K., R. Parker, and E.P. Fuerst. 1992. Foliar absorption and translocation of herbicides from aqueous solution and herbicide-treated soil. Weed Sci. 40:281-287.

Bowes, G. 1981. Improving aspen poplar and prickly rose-covered rangeland with herbicides and fertilizer. Can. J. Plant Sci. 61:401-405.

Derr, J.F. 1989. Multiflora rose (Rosa multiflora) control with metsulfuron. Weed Technol. 3:381-384.

Horst, K.R. 1983. Compendium of rose disease. APS Press, St. Paul, Minn. p. 50.

Meyer, R.E. and R. W. Bovey. 1984. Response of Macartney rose (Rosa bracteata) and understory vegetation to herbicides. Weed Sci. 32:63-67.

Meyer, R.E. and R. W. Bovey. 1990. Influence of sulfonylurea and other herbicides on selected woody and herbaceous species. Weed Sci. 38:249-255.

Neter, J., W.W. Wasserman, and M.H. Kutner. 1985. Residual analysis. p. 609-615. In: Applied linear statistical models, regression, analysis of variance, and experimental design. 2nd ed. Irwin, Homewood, Ill. 